\title{
Use of bronchoalveolar lavage in the evaluation of methotrexate lung disease
}

\author{
GEORGES M AKOUN, CHARLES M MAYAUD, JEAN L TOUBOUL, \\ MICHEL F DENIS, BERNARD J MILLERON, JEAN Y PERROT
}

From the Centre de Pneumologie et de Réanimation Respiratoire, Hôpital Tenon, Paris

ABSTRACT The results of bronchoalveolar lavage in three patients with a presumptive diagnosis of methotrexate induced lung disease are presented. Lavage fluid was characterised by the presence of large numbers of lymphocytes, which in two patients were predominantly lymphocytes of the $\mathrm{T} 8$. phenotype. These findings further support the hypothesis that immune mediated mechanisms mays play a part in the pathogenesis of this disorder in some patients, and indicate that bronchoalveola $\frac{\mathbb{P}}{\mathbb{P}}$ lavage may be helpful in the evaluation of patients suspected of having methotrexate induced lung disease.

Pulmonary damage associated with methotrexate administration is a common clinical problem in patients receiving this drug. The clinical manifestations of this disorder have been described in detail. ${ }^{1}$ Nevertheless, the diagnosis remains difficult to establish since no pathognomonic features have been described, and even invasive techniques such as open lung biopsy cannot firmly establish the diagnosis.

We report here three cases of methotrexate lung in which bronchoalveolar lavage was performed. Our findings support the hypothesis that cell mediated immune responses may be important in the pathogenesis of the disease and suggest that, in the appropriate clinical setting, bronchoalveolar lavage may be useful in evaluation of patients suspected of having developed this disorder.

\section{Methods}

Bronchoalveolar lavage was performed by a technique based on the method of Reynolds and Newball. $^{2}$ Following fibreoptic bronchoscopy four $50 \mathrm{ml}$ aliquots of $0.9 \%$ sodium chloride were instilled into the right middle lobe bronchus. Fluid was recovered by gentle suction after each aliquot, filtered through gauze, and placed on ice. Total cell counts were determined with a haemocytometer, and a differential cell

Address for reprint requests: Professor G M Akoun, Centre de Pneumologie et de Réanimation Respiratoire, Hôpital Tenon, 75020 Paris, France.

Accepted 18 February 1987 count was obtained by counting 1000 cells after May $\stackrel{\infty}{-}$ Grünwald-Giemsa staining of cytocentrifuge prepa rations. In two patients helper and suppressor $T_{S}^{0}$ lymphocyte subsets were determined by immunofluorescence microscopy with T4 and T8 monoclonah antibodies respectively (Ortho Diagnostics, Raritan, New Jersey). In view of the patient's clinical condition provocation tests were not performed. Results wereo compared with those obtained from bronchoalveolar lavage of 18 normal healthy volunteers.

Peripheral blood mononuclear cells were isolated. by centrifugation on Ficoll-Hypaque density gra dients. Total cell counts, differential cell counts, ando evaluation of lymphocyte surface phenotype were determined as described above for lavage cells 3 . Results have been compared with those obtainedo from 20 healthy adults (normal controls) and from? three patients treated with methotrexate but free fromo interstitial pneumonitis (methotrexate controls).

\section{Case reports}

CASE 1

A 42 year old woman, a non-smoker, presented with a malignant trophoblastic tumour following as hydatidiform mole. Hysterectomy was performed and the patient was given combination chemotherapy fof three months with cyclophosphamide, vincristine and methotrexate. During this period a rash occurred after one injection of methotrexate and disappeareb spontaneously within 24 hours. Ten days after the las $\overrightarrow{\mathbb{Q}}$ course of combination treatment $50 \mathrm{mg}$ methotrexatep was administered alone intramuscularly every five 
Numbers and types of cells recovered by bronchoalveolar lavage from three patients with methotrexate lung disease and 18 normal controls

\begin{tabular}{|c|c|c|c|c|}
\hline & Controls* & Case 1 & Case 2 & Case 3 \\
\hline $\begin{array}{l}\text { Fluid recovered (\%) } \\
\text { Total cells }\end{array}$ & $54(15)$ & $37 \cdot 5$ & 40 & $37 \cdot 5$ \\
\hline $\begin{array}{l}\text { Cells } \times 10^{3} / \mathrm{ml} \\
\text { Macrophages }\end{array}$ & $112(37)$ & ND & 497 & 220 \\
\hline $\begin{array}{l}\text { Cells } \times 10^{3} / \mathrm{ml} \\
\text { Neutrophils }\end{array}$ & $\begin{array}{r}91(4) \\
102(6)\end{array}$ & $\begin{array}{l}21 \\
\text { ND }\end{array}$ & $\begin{array}{r}44 \\
218\end{array}$ & $\begin{array}{l}38 \\
83\end{array}$ \\
\hline $\begin{array}{l}\% \\
\text { Cells } \times 10^{3} / \mathrm{ml}\end{array}$ & $\begin{array}{l}1(1) \\
1 \cdot 12\end{array}$ & $\stackrel{4}{\text { ND }}$ & $\begin{array}{c}6 \\
29 \cdot 8\end{array}$ & $\begin{array}{l}2 \\
4 \cdot 4\end{array}$ \\
\hline $\begin{array}{l}\text { Cells } \times 10^{3} / \mathrm{ml} \\
\mathrm{T}^{+} \text {lymphocytes }\end{array}$ & $\begin{array}{c}8(3) \\
10(10)\end{array}$ & $\begin{array}{l}75 \\
\text { ND }\end{array}$ & $\begin{array}{c}50 \\
248 \cdot 5\end{array}$ & $\begin{array}{r}60 \\
132\end{array}$ \\
\hline $\begin{array}{l}\text { Cells } \times 10^{3} / \mathrm{ml} \\
\mathrm{T}^{+}{ }^{+} \text {lymphocytes }\end{array}$ & $\begin{array}{l}50(11) \\
5(5)\end{array}$ & $\begin{array}{l}\text { ND } \\
\text { ND }\end{array}$ & $\begin{array}{l}28 \\
69 \cdot 5\end{array}$ & $\begin{array}{l}15 \\
19 \cdot 8\end{array}$ \\
\hline $\begin{array}{l}\text { Cells } \times 10^{3} / \mathrm{ml} \\
\text { T4:T8 ratio }\end{array}$ & $\begin{array}{l}30(7) \\
3(3) \\
1 \cdot 8(0 \cdot 7)\end{array}$ & $\begin{array}{l}\text { ND } \\
\text { ND } \\
\text { ND }\end{array}$ & $\begin{array}{r}56 \\
139 \cdot 16 \\
0.50\end{array}$ & $\begin{array}{l}35 \\
46 \cdot 2 \\
0 \cdot 43\end{array}$ \\
\hline
\end{tabular}

* Results for controls are expressed as means with standard deviations in parentheses.

ND-not done.

days for three weeks (cumulative dose $200 \mathrm{mg}$ ). During this period she noted the onset of fever $\left(39^{\circ} \mathrm{C}\right)$, cough, dyspnoea on exertion, and a transient rash. She was given $40 \mathrm{mg}$ methylprednisolone intravenously and $2 \mathrm{~g}$ erythromycin for three days. Subsequently she was referred to our department because of the persistence of respiratory symptoms. On admission, crackles were heard over both lung bases and chest radiography showed small opacities in both lung fields but predominantly on the right. The arterial oxygen tension $\left(\mathrm{PaO}_{2}\right)$ was $6.65 \mathrm{kPa}$. The peripheral blood eosinophil count was $280 \times 10^{3} / 1$. Broncheoalveolar lavage was performed (table). The patient required mechanical ventilation, and treatment with rifampicin, isoniazid, and ethambutol was begun. Eight days later all clinical and radiological abnormalities had disappeared, allowing extubation and cessation of antituberculous drugs. $\mathrm{PaO}_{2}$ was $10.37 \mathrm{kPa}$. Hepatic and bone marrow biopsy specimens showed no histological abnormalities.

\section{CASE 2}

An 18 year old woman, a non-smoker, with acute myeloid leukaemia was given $15 \mathrm{mg}$ of methotrexate intrathecally every week for three months as part of a combination chemotherapy course that also contained cytosine arabinoside, rubidomycirt, cyclophosphamide, and vincristine (cumulative dose of methotrexate $180 \mathrm{mg}$ ). A few days after the last methotrexate injection she developed dyspnoea on exertion and fever $\left(38 \cdot 8^{\circ} \mathrm{C}\right)$. Clinical examination was unhelpful. Chest radiography showed extensive small nodular opacities in both lungs. $\mathrm{PaO}_{2}$ was $6.91 \mathrm{kPa}$. There was no peripheral blood eosinophilia. Pulmonary function test results were consistent with a restrictive ventilatory defect with a low vital capacity (64\% predicted) and reduced pulmonary compliance $\left(1 \cdot 131 \mathrm{kPa}^{-1}\right)$. Bronchoalveolar lavage was performed (table). Methotrexate treatment was withdrawn and $500 \mathrm{mg}$ methylprednisolone was administered intravenously. At the same time she was treated for four days with penicillin $\mathrm{G}$, rifampicin, isoniazid, and ethambutol. Histological examination of a liver biopsy specimen showed no abnormality. Three days later all clinical, radiological, and blood gas abnormalities had resolved. After one month the results of pulmonary function tests were normal. The other chemotherapeutic agents were later reintroduced without adverse effects.

\section{CASE 3}

A 62 year old woman, a non-smoker, with breast cancer underwent a mastectomy followed by radiotherapy and was then given combination chemotherapy with 5-fluorouracil, cyclophosphamide, vincristine, and methotrexate $(25 \mathrm{mg}$ methotrexate intravenously every week for two months, cumulative dose $200 \mathrm{mg}$ ). A few days after the last injection she complained of dysponoea and fever $\left(38^{\circ} \mathrm{C}\right)$. Crackles were heard in both lungs. Chest radiograph showed extensive small nodular opacities. Pulmonary function tests showed decreased vital capacity and pulmonary compliance; $\mathrm{PaO}_{2}$ was $6.25 \mathrm{kPa}$. Bronchoalveolar lavage was performed (table). Bronchial biopsy specimens showed no histological abnormalities and the serum carcinoembryonic antigen concentration was normal. Twenty one days after methotrexate was withdrawn, and without any antibiotic administration, the clinical and radiological abnormalities had disappeared and the $\mathrm{PaO}_{2}$ had risen to $9.96 \mathrm{kPa}$. Three months later the results of pulmonary function tests were normal.

\section{Results}

In each patient the lavage fluid was characterised by a large increase in the number of lymphocytes and a smaller increase in the number of neutrophils recovered (table). This lymphocytosis resulted from an increase in number of T4 and T8 positive cells, but there was a disproportionate expansion of T8 lymphocytes in the two patients in whom this was studied, resulting in a low T4:T8 ratio.

Less striking changes appeared in the peripheral blood leucocytes. Two of three patients were lymphopenic, presumably as a result of chemotherapy. The T4:T8 ratio in peripheral blood was at the lower limit of normal in the two patients evaluated $(1.1$ and 0.8 
for patients 2 and 3 respectively). Patients receiving methotrexate without evidence of pulmonary toxicity also tended to have a lower T4:T8 ratio than that seen in normal subects, although this difference was not significant in our small series (methotrexate $(n=3)$ 1.2 (SD 0.9); normal subjects $(\mathrm{n}=20) 1.8(0.4)$; $\mathrm{p}>0 \cdot 2$ ). Eosinophilia was not present in any of our patients.

\section{Discussion}

The presence of a large increase in the number of lymphocytes and a modest increase in the number of neutrophils in the lower respiratory tract was a consistent finding in our three patients with methotrexate lung disease. This is in agreement with the data reported by White et al. ${ }^{3}$ In contrast to their report, however, we found the T4:T8 ratio of lavage lymphocytes to be low in the two patients whose lymphocyte subsets were evaluated.

Lung biopsy was not undertaken in any of our patients. Bronchoalveolar lavage data were, however, consistent with the cell types seen in biopsy specimens reported by others (for example, lymphocyte and monocyte with or without eosinophil infiltration and granuloma formation). ${ }^{4-6}$

Several other clinical features reported here would favour a diagnosis of methotrexate lung disease. Firstly, the patients had recently received methotrexate in $\operatorname{doses}^{6}$ and by routes ${ }^{7}$ previously reported to produce this disorder. The clinical symptoms, the findings from physical examination, the chest radiographs, and the results of pulmonary function tests were compatible with the diagnosis, ${ }^{4-5}$ as was the rapidly favourable clinical outcome on withdrawal of methotrexate with or without corticosteroid treatment. ${ }^{6}$

Secondly, no other explanation for the pulmonary disorders could be found by other investigations. The patients denied exposure to antigens known to be associated wth extrinisic allergic alveolitis ${ }^{8}$ and investigations failed to reveal any recurrence of cancer. Examination of sputum and bronchoalveolar lavage fluid detected no viral, fungal, bacterial, or parasitic pathogens in any of the cases. One patient (case 3) was found to have cytomegalovirus in the urine and developed antibodies to the virus. Viral cultures of lung secretions were, however, negative; viral inclusions were not seen in cells recovered by lavage; and the clinical course was not typical of cytomegalovirus pneumonia.

Finally, we believe that drug induced lung disease resulting from other therapeutic agents is unlikely for several reasons. Patient 1 was receiving only methotrexate when acute symptoms developed. Patient 2 was later rechallenged with the other chemo-
Akoun, Mayaud, Touboul, Denis, Milleron, Perro.t

therapeutic agents she had been receiving before the onset of pulmonary symptoms without adverse effects. Patient 3 had been receiving several drugs when symptoms appeared. Cyclophosphamide m produce pneumonitis. ${ }^{9}$ Nevertheless bronchoalveol lavage findings in patient 3 were not characteristic of those previously reported in cyclophosphamide induced abnormality of lavage fluid, ${ }^{10}$ in which a nettrophil excess was observed even though lymphocytie interstitial infiltrates are usually present in lugg biopsy specimens. ${ }^{11}$ Furthermore, rapid clinic improvement after discontinuation of treatment is unusual in this disorder. ${ }^{19}$ To our knowledge, vif cristine has not been reported to produce pulmonasy toxicity, although other Vinca alkaloids may produse lung disease. ${ }^{1213}$ Finally, cytosine arabinoside h@s been considered responsible for one case of pul. monary oedema without lymphocytic infiltration, $\mathbb{C}^{A}$ and rubidomycin and 5-fluorouracil have never been reported to produce pulmonary toxicity. ${ }^{9}$ Neve theless, while methotrexate lung disease remains o clinical diagnosis the pathogenetic role, if any, of infection or other therapeutic agents in our patients $\overrightarrow{\dot{c}}$ by no means clear.

The bronchoalveolar lavage findings in our patients with methotrexate induced lung disease are similar those observed in lavage fluid from patients wi extrinsic allergic alveolitis ${ }^{81516}$ and in drug assooiated pulmonary hypersensitivity reactions seen after administration of various therapeutic agents. ${ }^{17-q_{8}}$ Thus our results are consistent with the possibility that drug induced cell mediated hypersensitivity reaction in some patients plays a part in methotrexate lung disease. Further studies are required to firmlly establish the pathogenesis of this disease.

Our results also suggest that lavage may prove usieful for the evaluation of patients suspected of having methotrexate lung disease. We should emphasise that the pattern of lavage findings should not be considered diagnostic of methotrexate lung disease, sinceja similar pattern can be seen in various other lugg hypersensitivity reactions. Nevertheless, in an appropriate clinical setting an excess of lavage lymphocy and a low T4:T8 lung lavage lymphocyte ratio may be useful in suggesting the presence of methotrexate luogg disease.

We thank Dr A Hance for useful discussions, Ms Bellaiche for providing blood samples from contri patients, Ms C Henry for the preparation of this manuscript, and Ms M Michalon for her secretara assistance.

\section{References}

1 Batist G, Andrews JL. Pulmonary toxicity of antineoplastic drugs. JAMA 1981;246:1449-53. 
2 Reynolds HY, Newball HH. Analysis of proteins and respiratory cells obtained from human lungs by bronchial lavae. J Lab Clin Med 1974;84:559-73.

3 White DA, Gellene R, Rankin JA, Gupta S, Cunningham-Rundles C, Stover DE. Methotrexate pneumonitis: bronchoalveolar lavage findings [abstract]. Am Rev Respir Dis 1984;129:A64.

4 Clarysse AM, Cathey WJ, Cartwright GE, Wintrobe MM. Pulmonary disease complicating intermittent therapy with methotrexate. JAMA 1969;209:1861-4.

5 Rawbone RG, Shaw MT, Jackson JG, Bag Shan KD. Complications of methotrexate maintained remission in lymphoblastic leukaemia. Brit Med J 1971;iv:467-8.

6 Sostman RD, Matthay RA, Putman CE, Smith GJN. Methotrexate induced pneumonitis. Medicine (Baltimore) 1976;55:371-88.

7 Gutin PH, Green MR, Bleyer WA, Baller VL, Wiern JKP, Walker MD. Methotrexate pneumonitis induced by intrathecal methotrexate therapy. Cancer 1976;38:1529-34.

8 Molina C. Bronchopulmonary immunopathology. Edinburgh: Churchill Livingstone, 1976:58-127.

9 Akoun G, Mayaud C, Milleron B, Francois Th, Herman DP, Touboul JL. La pathologie pulmonaire d'origine médicamenteuse. In: Laffont A, Durieux F, eds. Encyclopedie Medico-Chírurgicale. Paris: Editions Techniques, 1985: 6019 (A90):1-20.

10 Akoun G, Mayaud C, Touboul JL. Diagnostic value of bronchoalveolar lavage in drug-induced interstitial pneumonitis [abstract]. Respiration 1984;46(suppl. 1): 71.
11 Cooper JAD, White DA, Matthay RA. Drug-induced pulmonary disease. Am Rev Respir Dis 1986;133: 321-40.

12 Kris MG, Pablo D, Gralla RJ, Burke MT, Prestifilippo $\mathrm{J}$, Lewin D. Dyspnoea following vinblastine or vindesine administration in patients receiving mitomycin plus vinca alkaloid combination therapy. Cancer Treat Resp 1984;68:1029-31.

13 Luedke D, McLaughlin TT, Daughaday C, et al. Mitomycin $C$ and vindesine associated pulmonary toxicity with variable clinical expression. Cancer 1985; 55:542-5.

14 Haupt HM, Hutchins GM, Moore GW. Ara C lung: non cardiogenic pulmonary oedema complicating cytosine arabinoside therapy of leukaemia. $\mathrm{Am} J \mathrm{Med}$ 1981;70:256-61.

15 Hirata T, Nagai S, Ohshima S, Izumi T. Comparative study of T-cell subsets in BAL fluid in patients with hypersensitivity pneumonitis and sarcoidosis. Chest 1982;82:232.

16 Leatherman JW, Michael AF, Kronenberg RS, Schwartz BS, Hoidal JR. Evaluation of cell-mediated immunity in the lung by monoclonal antibodies in hypersensitivity pneumonitis and asymptomatic pigeon breeders [abstract]. Am Rev Respir Dis 1983; 127(suppl):62.

17 Ettensohn DB, Roberts NJ, Condemi JJ. Bronchoalveolar lavage in gold lung. Chest 1984;85:569-70.

18 Akoun GM, Mayaud CM, Milleron BJ, Perrot JY. Drug-induced pneumonitis and drug-induced hypersensitivity pneumonitis. Lancet 1984;i:1362. 